\title{
Challenges to Global Security: Population Health
}

\author{
Diah Ayu Permatasari ${ }^{1{ }^{*},}$, Noam Lazuardy ${ }^{2}$ \\ ${ }^{1}$ Faculty of Communication; Universitas Bhayangkara Jakarta Raya; Jl. Perjuangan , \\ Marga Mulya, Bekasi Utara; 02188955882/+622188955871; e-mail: pepy@ubharajaya.ac.id \\ 2 School of Graduate Studies; National University of Management; St.96 Christopher \\ Howes, Phnom Penh, +85523428120/+85523427105; \\ e-mail: noamno13laz@yahoo.com
}

\begin{abstract}
Population health is one of the some challenging in global security. This trend poses new challenges and opportunities for global public health, which is centrally concerned with identifying and addressing threats to the health of vulnerable populations worldwide. Rapid population growth has to be controlled by amount and equalization by demographic. Demographic policy no doubt lies within the national jurisdiction of sovereign states. The resolution of demographic policy has to be resolved between countries. All the countries have a role to play in setting goals, and with the cooperation with WHO and WTO. Multilateral cooperation are needed to create global security to promote health for its population globally.
\end{abstract}

Keywords: Population, Health, Cooperation, Multilateral

\begin{abstract}
Abstrak
Kesehatan penduduk adalah salah satu dari berbagai tantangan dalam keamanan global. Tren tersebut menghadirikan tantangan dan peluang baru bagi kesehatan masyarakat global, yang secara menyeluruh berkaitan dengan identifikasi dan penanganan ancaman terhadap kesehatan populasi yang rentan di seluruh dunia. Pertumbuhan penduduk yang cepat harus dikendalikan oleh jumlah dan pemerataan demografis. Kebijakan demografis tidak diragukan lagi terletak pada yurisdiksi nasional masing - masing negara. Resolusi kebijakan demografis harus diselesaikan antar negara. Semua negara memiliki peran untuk dilakukan dalam menetapkan tujua dengan bekerja sama dengan WHO dan WTO. Kerja sama multilateral diperlukan untuk menciptakan keamanan global guna meningkatkan kesehatan penduduksecara global.
\end{abstract}

Kata kunci: Populasi, Kesehatan, Kerja Sama, Multilateral

\section{Introduction}

Population is experiencing unprecedented demographic change around the world. The explosions of human numbers are increasing time to times. The world population has grown tremendously over the past two thousand years, the latest official current world population for year 2020 is 7,7 billion. It is estimated 11 billion around 2100 (Bashford, 2008). This huge number of populations is part of globalization development over the world.

The definition of "Health" as given by WHO "as a state of complete physical, mental and social well-being and not merely an absence of disease or infirmity" has never been the ideal definition and people relate that health is dynamic in nature and besides the three dimensions, there are also spiritual, vocational, behavioral and environmental dimensions that need to be considered (Canon, 2009).

Globalization - defined here as the increasing (and increasingly less restricted) flow of money, people, information, technology, ideas, etc. throughout the world - remains an important, and perhaps evens the dominant, influence (Wilson, 2001). In this definition we can share that human is one of the most important part of globalization. 
The globalization is an extremely complex phenomenon, but it has to secure all the communities and people to get sufficient and better life. Globalization development has to be balance with their global security. In this term of Global Security means the efforts taken by the community of nations to protect against threats which are transnational in nature. There are so many treats and restricted in globalization, by encouraging and consolidating the positive aspects of globalization, will be a continuing challenge to get best solution.

Population health is one of the some challenging in global security. This trend poses new challenges and opportunities for global public health, which is centrally concerned with identifying and addressing threats to the health of vulnerable populations worldwide. The rapid growth of population is expanding a growing influence in the world, particularly in Asia, Africa and Latin America. There has been growth in the world population that is unprecedented in human history both in its rates and absolute magnitudes.

Population health sees globalization as a threat to international health. On the relatively the focus on the indirect effects' economy related to health population is when poverty is the major determinant of health in poor countries. Most rapid growth of population is in development countries when they had problems of economic and health.

Health became major concern of the globalization at least since the plague of Athens in 430 BC killed approxiamtely as much as one third of the population (Deaton, 2004). Deaton said there are some data related to health and globalization and international attempt to prevent it. The city states of northern Italy developed the first systems of national and international public health in their attempts to control recurrent episodes of the disease. In 1851, the first international sanitary conference was held in Europe, as the rising volume of international trade, driven by reductions in costs from better ships and railways came into conflict with national health measures. International public health has always been as much concerned with facilitating trade as with protecting, the quarantine measures became methods of discrimination and exclusion, not only for the absence of threats to public health.

The rapid growth of population is expanding a growing influence in the world, particularly in Asia, Africa and Latin America. There has been growth in the world population that is unprecedented in human history both in its rates and absolute magnitudes. Major reason why the present demographic situation is a global problem because rapid population growth is taking place in Asia, Africa and Latin America (developing countries) whose share in world population already exceeds two thirds. Because of their economic, social and cultural backwardness, there is tending which these countries are unable to supply their population. In the other hand, total population in advance or rich nations is near zero and aging population.

Rapid population growth and imbalance spread also produces other problems specific to these countries and over the world. As the world around us is becoming progressively interconnected and complex, human health is increasingly perceived as the integrated outcome of its ecological, social-cultural, economic and institutional determinants.

There are some problems when the growing population and globalization security met the unbalance progress, i.e.:

1. Food security

Poorer states, or those with weak governance, will experience additional strains on their resources, infrastructures, and leadership. Many will struggle to cope; some will undoubtedly fail. Less food, mall nutrition is a first step to the unhealthy world population.

2. Natural Resources

The direct relation between growing world population and global problems is the supply natural resources. Poor countries cannot guarantee all the growing people get sufficient nutrition, water and energy.

3. Job security

Concern changes is age structure where people under 15 has increased to $40-50$ percent of the population in most developing countries, while in the advance country they population almost zero growth. There will be a time when all productive age in some countries facing problems to fulfill their surveillance of living. Hard competition and lack of opportunities has to be solved in growing population.

4. Migrant-borders

When the demographic is uneven between west and east, there will be migration between density communities to the rural. This issue is makes globalization must open between all the borders or it can be threat to each national security. 
5. Environment population

More People need more food to eat, more energy to use and more pollutions. The air pollution and health factors, including the water crisis, will put most of the other issues to shame. This environment factors are big concerning over the world, we have to keep the living world for futures.

6. Lifestyle

Due to the widespread flow of people, entertainment, culture, information and ideas, lifestyles also spread throughout the world. It is already widely acknowledged and demonstrated that several modern behavioral factors such as an unhealthy diet, physical inactivity, smoking, alcohol misuse and the use of drugs are having a profound impact on human health.

7. Borderless disease

One of the most mentioned health effects of globalization is the spread of infectious diseases. From the past histories, diseases have been linked to factors that are related to the globalization process. The recent outbreak of the Severe Acute Respiratory Syndrome (SARS) and Covid 19 demonstrates the potential of new infectious diseases to spread rapidly in today's world, increasing the risk of a global pandemic in the previous years. It is easy to spread crossing all border nations and carried by the travelers.

All these problems influencing population health when a comprehensive analysis to the global security. However, the identification of all possible health effects of the globalization process goes together with the dynamics of our global system following important features of the globalization process: new global governance structures, global markets, global communication and diffusion of information, global mobility, cross-cultural interaction, and global environmental changes. The spread of infectious diseases is probably one of the most mentioned health effects of globalisation and past disease outbreaks have been linked to factors that are related to the globalisation process (Newcomb, 2003).

In the 1980s and 1990s, there was a broad increase in world incomes, and a reduction in poverty, both as a fraction of the world's population, and in absolute numbers. It never been imagined happened when the Covid-19 pandemic spread out to the world since 2019. The world has stopped completely due to virus problems that caused causalities and losses both material and non-material. Covid-19 has made the world aware that health security is a prominent point for the progress and success of the Nation.

The globalization might have had something to do with these challenges, globalization comes from the idea for better life. It is improving that higher attempt to promote better health. Globalization also affects health indirectly through social determinants of health, such as employment and economic growth. The liberalization of trade regulations has created enormous economic opportunities for skilled labor forces. The new employment has led to large-scale poverty reduction and improvement in some health outcomes in the countries. That growth was a powerful engine to reduce poverty and steps to increasing population health.

Nevertheless, globalization also brings diseases that cannot be controlled by the very active mobility of people and goods including bad effects that are detrimental to the world community. The impact of Covid-19 does not only affect health but also other sectors, namely the economy, politics, social and even culture. According to Held et al. (1999) tourism is one of the most obvious forms of cultural globalisation and it illustrates the increasing time-space compression of current societies.

With the growth of civil society and the enormous new funding for global health from the private sector, new concepts of governance involving non-state actors are needed. Foreign policy in the new era of global health governance has opportunities to see corporation between countries to world health population. Therefore, partnership help to put health in all policies (Kikcbusch and Quick, 1998), that they will improve self regulation (Mello et. all, 2008).

Globalization has affected the health of people around the globe in less visible ways too. The transfer between complex medical technologies with hospital safety standards in some middle-income countries combined with cheap air travel have created cross-national health care markets with effects on access to health care in richer and poorer countries.

Globalization compromises access to health care for local residents as doctors increasingly leave the public sector and general medicine for more remunerative practice in private specialty hospitals. Another defining feature of globalization is population movement 
across borders. Highly trained health professionals emigrate in increasing numbers from poorer to richer countries to meet the growing demand for health care caused by aging populations and shortages of doctors and nurses.

Globalization includes a phenomenon and risks that affects the sustainability of health systems and public health. This matter involved not only National health systems in countries, but also National health has become trans-nationalized. Governments is no longer the solely actors in national health systems, but there were various worldwide institutions such as WHO, UNICEF, WB, WTO, UNFPA, UNDP etc. whose involved in population health for global security. It is also regional cooperation affect directly or indirectly the functioning of national health systems and international health populations ${ }^{1}$.

\section{Method}

A case study is useful to purposely discover a context and verify its connection to a specific research objective. It allows the researcher to explore individuals or organizations, simple through complex interventions, relationships, communities, or programs (Yin, 2003) and supports the deconstruction and the subsequent reconstruction of various phenomena. Use of a case study enabled discovery of the existing practices and past experiences of the global health population, and to understand the perspectives on how countries as well as the cooperation with stake holders and multilateral organization can contribute as well as to promote the global health for the world population.

\section{Result And Discussion}

Rapid population growth has to be controlled by amount and equalization by demographic. For develop countries whose already exceeds of human number should control their communities by government policy in controlling population and promote the contraception with the International aid if it is necessary.

Demographic policy no doubt lies within the national jurisdiction of sovereign states. Their difficulties in solving their demographic problems already influenced international situation as a whole, and that a failure by individual countries to solve these problems independently during the next several decades could not only bring highly unfavorable social consequences to those countries but could also influence the world economy, international political affairs and the interests of the human race. The resolution of demographic policy has to be resolved between countries. The problem of demographic is not only for the number but also the distribution of the age. It will be affected to the politic and geopolitic (Bashford;2008). The problem of covid 19 related to the demographic and the globalization, wherein uncertainty is the key word in this problem, making it difficult to solve. This has an impact on all sectors of life and is able to slow down the economic activity and mobility in population health.

In such circumstances, some solutions to facing global security challenges in population health are:

1. Economic development and Trading

The growth dynamics of economic globalization is significant in the developing world, with the strong economic usually increase the education, health understanding and standard of living.

2. Health(-related) policies

Global governance structures are gaining more and more importance in formulating health (-related) policies. One of the most important organizations in global health governance is the World Health Organization (WHO). It has major role to supervise population health in the globalization era. Others important organizations are the World Bank (WB) and WTO (Dodgson et. al, 2002), It plays an important role in the field of global health governance as it acknowledges the importance of good health for economic development and focuses on reaching the Millennium Development Goals.

3. Development of public-private partnerships for health, at the global level, public-private partnerships are more perceived as a possible new form of global governance. 
Governments increasingly attract private sector companies to undertake tasks that were formerly the responsibility of the public sector. The immense threat to health cannot be tackled by government alone (Cannon, 2009)

4. Social interactions: social equity and social networks - health protocols

Cultural globalization (global communication, global mobility, cross-cultural interaction) can also influence cultural norms and values about social solidarity and social equity between poor countries and rich countries together unify the health population. The geographical scale of social networks is increasing due to global communications and global media. The women's movement, the peace movement, organized religion and the environmental movements are good examples of such transnational social networks. The interesting thing is that the implementation of health protocol that must be applied in social interactions to maintain health security and reduce the impact of diseases, one of which is Covid-19.

5. Information, technology and knowledge

The diffusion of new technologies, new information and ideas has enabled people to gather and process data in no time resulting in increased amounts of empirical data to solve population health problems. New technologies have even broadened the character of literacy. In addition, television, film and computer graphics have greatly enlarged the visual dimensions of communication.

6. Ecosystem and environmental maintained

Global environmental changes can have profound effects on the provision of ecosystem goods and services to mankind. Basically, the following types of 'health functions' can be distinguished. First, ecosystems provide us with basic human needs like food, clean air, clean water and clean soils. Second, they prevent the spread of diseases through biological control. Finally, ecosystems provide us with medical and genetic resources, which are necessary to prevent or cure diseases. The climate change can result in significant ecosystem disruptions and threatens substantial damage to the earth's natural systems, with the understanding all the population should keep the good and maintain environment to the future.

7. International public health in their attempts to control and quarantine of the disease. The spread of virus or disease can be halted when every border has their attempts to control and checked as maximum as they can to reduce the spread of disease in the world.

8. Increasing of population Health by medical treatment such as vaccination, invention of cure of disease, increasing detection of preliminary health and international aids to accessibilities of health provider.

All of these can be the solutions facing the security challenges including the pandemic covid 19, accelerated key word is enhancing the cooperation and collaboration of all world's stakeholders to fight Covid-19 and efforts to maintain world health and peace. Therefore, strong action is needed as no special account of the great uncertainty that was present on the onset of the global pandemic (Reddy, 2020)

\section{Conclusion}

Great health for all world populations has become an accepted international goal of global security and we can state that there have been broad gains in life expectancy over the past century. But health inequalities between rich and poor communities, while the prospects for future health depend increasingly on the relative new processes of globalization. In the past globalization has often been seen as part of economic process. Nowadays it is increasingly perceived as a more comprehensive phenomenon, which is shaped by a multitude of factors and reshaping our society rapidly.

The world population has grown tremendously and imbalance spread also produces other problems specific to the countries and over the world. In this era planning for social and economic development, it is increasingly realized that demographic measures are among key factors in the planning process. The future size, structure and distribution of population are essential for any plan that involves food, housing, employment, education, health or other public services.

Moreover, the developing countries which have rapid growth populations suffer from lack of specialized staff, advanced technology and state of the infrastructure, which makes it unsuitable for these countries. Extensive transport and better communication facilitate trade, 
massive cross border movements of people rendering the local people vulnerable to harmful goods, disease and harmful lifestyles that directly or indirectly affect the health of the individual and community.

The Population, Health and Security node examines security challenges including natural disease threats, unregulated population movements, and demographic transitions. Focusing on the relationship between health and global security, this recognition that health has become a major international issue transcending national boundaries. Issues such as food security, disease, environmental change, population structure and mobility, force us to reconsider the aim of population health in global security. The focus of population health is to improve health and quality of life through the world globalization.

During the pandemic of Covid19, there are very big problems that occurs on all aspects of live, in which there are also several challenges over the population health in global security which facing almost all countries in the present and futures. The global health corporation (individual, nation or world organization) was established to seek for global co-operation and support in dealing with public health issues at the global level.

Almost all the countries have a role to play in setting goals for global security, this health priority setting, mobilization of funding and promote, advocate and develop mechanisms for international cooperation to gear up surveillance in population health besides strengthening internal resources, information, education, infrastructure and accessibilities. The trade liberalization and economic globalization have major role increasing health populations and education related to the promotion of health community especially in many developing countries.

The role of world organizational such as WHO in international trade agreements under WTO in ensuring that health is taken into account when trade policies are being framed, and in setting appropriate standards or formulating policies for promotion and protection of public health, needs to be re-emphasized and reviewed as per the necessity arises. Multilateral cooperation are needed to create global security to promote health for its population globally.

\section{Refferences}

1. Bashford, Alison (2008). Population, Geopolitics, and International Organization in the Mid Twentieth Century. Journal of World History. Vol. 19 No. 3, New Histories of United Nations (Sep.2008); pp. $327-347$

2. Cannon G. (2009). Out of the box. Public Health Nutr; 12:732-4. https://doi. org/10.1017/S1368980009005370.

3. Deaton, Angus (2004). Health in an age of globalization. Princeton University

4. Dodgson R, Lee K, Drager N. (2002). Global health governance: a conceptual review. Centre on Global Change and Health, London School of Hygiene and Tropical Medicine, London.

5. Fidler, David P, (2001). The globalization of public health: the first 100 years of international health diplomacy. Bulletin of the World Health Organization, WHO.

6. Held D, McGrew AG, Goldblatt D, Perraton J (1999). Global transformations: politics, economics and culture. Stanford. Stanford University Press; 1999

7. Inozemtsev, N.N. (1981) Global Problems of Our Age. Progress Publisher, Moscow

8. Kickbusch I, Quick J. (1998). Partnerships for health in the 21st century. World Health Stat Q;51:68-74 http://www.ncbi.nlm.nih.gov/pubmed/9675811.

9. Mello MM, Pomeranz J, Moran P. (2008). The interplay of public health law and industry self-regulation: the case of sugar-sweetened beverage sales in schools. Am J Public Health. 2008;98:595-604. https://doi.org/10.2105/AJPH. 2006.107680.

10. Newcomb J (2003). Biology and borders: SARS and the new economics of bio-security. Bio Economic Research Associates, Cambridge - UK.

11. Reddy SG (2020). Coronavirus and the limits of economics. Available: https://foreignpolicy.com/2020/03/31/coronavirus-pandemicrethinking-economics/

12. Wilson, Thomas R (2001). Global Threats and Challenges Through 2015. United States of America

13. Yin, R. K. (2003). Case study research: Design and methods (3rd ed.). Thousand Oaks, CA: Sage. 